Ann. Génét. Sél. anim., 1982, 14 (3), 369-380

\title{
Egg and yolk production traits in relation to ovum development, liver and liver moisture weight in dwarf and normal White Leghorns
}

\author{
A.K. BANERJEE, P. MÉRAT *, A. BORDAS * \\ Dept. of Animal Science, G.B.Pant University of Agriculture and Technology, \\ Pantnagar, India \\ * I.N.R.A., Laboratoire de Génétique factorielle \\ Centre de Recherches zootechniques, F 78350 Jouy-en-Josas
}

\begin{abstract}
Summary
Data on egg and yolk production and on ovum development were obtained from White Leghorn $\mathrm{Dw}$ and dw hens belonging to 4 sire families between 52 and 56 weeks of age. Ovum development was followed by the fat-soluble dye incorporation technique. At the end of this perdiod, the birds were killed and body weight, liver weight and liver water content, as well as rapidly growing ovum weight and ovum number, were recorded. We obtained the following results.
\end{abstract}

1) Average daily yolk production and weight of active ova were higher in the Dw genotype. The number of actively developing ova was higher in Dw hens, but the difference between genotypes was significant only on postmortem examination.

2) The average number of follicles undergoing rapid development at any time, estimated from eggs laid during the dye-feeding period and the number observed on postmortem examination, corresponded well in both $\mathrm{Dw}$ and $\mathrm{dw}$ genotypes, suggesting that there was no intra-peritoneal absorption of yolk in this stock.

3) For cultch sizes greater than one, the dwarfs took $3 \mathrm{~h}$ longer than the normals to lay their first egg. This might be due to a longer stay in the oviduct or to delayed ovulation.

4) Although the overall difference was not significant, it was noticed that the rapid development of the ova in clutches of all lengths and at any position in the clutch was shorter in dwarfs.

5) The time between the end of ovum yolk deposition and the laying of the resulting egg was significantly longer in dwarfs.

6) The weight of the liver was significantly correlated with yolk weight and the duration of rapid ovum development in both $\mathrm{Dw}$ and $\mathrm{dw}$ genotypes. The laying rate was not correlated with liver weight, while the rate of yolk production was positively but nonsignificantly correlated with this trait in both Dw and dw genotypes. 


\section{Introduction}

HutT (1959) observed that the sex-linked dw gene reduced the rate of egg production in egg-type hens. These conclusions have been confirmed by other authors but, mainly due to body weight differences of the populations studied, there appears to be some disagreement concerning the extent of these effects.

Although ovarian follicular growth and maturation have been followed with the fat-soluble dye incorporation technique by several workers (WARREN \& CoNRAD, 1939 ; Lacassagne, 1957, 1960, 1962 ; Bacon \& Skala, 1968 ; Lyoshi, 1978) in laying hens, the effect of the $\mathrm{dw}$ gene on these characters has only been reported in a broiler population by JAAP \& MoHAMmadian (1969). The latter authors observed that $\mathrm{dw}$ reduced the rates of yolk deposition in the ovary but not yolk production in pullets weighing an average of $2.6 \mathrm{~kg}$ at 36 weeks of age.

Furthermore, O'HeA \& Leveille (1968) and Leveille (1969) concluded that the liver was the main site of fatty acid synthesis in chickens but GARLICH et al. (1975) and SHIVAPRASAD \& JAAP (1977) did not find any consistent associat:on between liver weight and the rate of yolk and/or egg production in laying hens.

This paper reports an attempt to determine the extent of the depressive effect of the dw gene in a low body-weight population on ovarian function and yolk production and the influence of the liver on these traits in White Leghorns.

\section{Material and methods}

\section{A. Birds and experimental conditions}

We used birds from the "heated》 group of the experiment described earlier by BANERJEE et al. (1981). These birds, sampled at 39 weeks of age on the basis of their egg production, included $10 \mathrm{Dw}$ and $10 \mathrm{dw}$ females belonging to 4 sire family groups. They were put into cages under normal temperatures (about 15 to $20^{\circ} \mathrm{C}$ ). The experiment was carried out for 36 days when the birds were between 52 and 56 weeks of age. During this time no mortality was observed, and the rate of egg laying and clutch size were low. Throughout the experimental period the birds received $14 \mathrm{~h}$ of light and $10 \mathrm{~h}$ of darkness per day. Water and feed were given ad libitum; the feed contained 16 p. 100 of total protein and approximately $2600 \mathrm{Kcal} / \mathrm{kg} \mathrm{ME}$.

\section{B. Traits measured or calculated}

Starting on 28-9-1981, each of the 20 birds was fed daily between 9 and $9.30 \mathrm{~h}$ a $0.68 \mathrm{ml}$ gelatin capsule containing about $15 \mathrm{mg}$ of either Sudan Black B (B) or Sudan IV (R). These dyes, fed in the sequence $R, B, R, B, B, R, B, R, B, R, B, B$, etc., gave a non-repetitive sequence of 12-day dye deposition in the ova of the subsequently laid eggs. This sequence allowed to determine to the nearest day when the first dye was deposited in the ovum entering rapid development the period during which yolk material was actively deposited and when rapid development stopped. Starting from 
29-9-1981, all the laid eggs were hard-boiled each day; after they had been cooled under running tapwater and immediately opened, the dye sequence deposited in the ovum was determined. The same person examined the dye sequence throughout the experiment. These 12-day sequences of dye administration were continued for a 36-day period. At the end of this period, all the birds were killed, and we collected or calculated the following data :

(1) egg number, rate of lay, clutch size and egg and yolk weight (of boiled eggs) during the dye-feeding period;

(2) the hour and the time between two successive ovipositions during the dyefeeding period; the hour of laying was recorded at $9,10,11,13,14$ and $17 \mathrm{~h}$;

(3) the duration of rapid ovum development (in days) by the fat-soluble dye incorporation technique;

(4) the time between the end of yolk deposition in the ovum and egg laying (in h). We assumed that the interval was constant between the time the dye was fed and the time of its deposition in the yolk. This time was calculated as follows : the dye was fed each day between 9 and $9.30 \mathrm{~h}$. It was supposed that after about $4 \mathrm{~h}$, i.e. at $13 \mathrm{~h}$, the dye had entered all the ova which were rapidly developing. Thus, in the dye sequence in each ovum laid, the last dye entering the ovum was presumed to have entered at $13.00 \mathrm{~h}$ the day it was fed. This time was taken as the minimal estimation of the end of rapid ovum development. The period (in $h$ ) between the end of this development and laying was studied;

(5) the rate of yolk deposition in the ovary. It was estimated in two ways : (i) by the daily rate of yolk production calculated from eggs laid during the dye-feeding period, just prior to slaughter, plus eggs in the oviduct on postmortem examination and (ii) by the total weight of rapidly developing ova, i.e. all those stained with dye. The estimate based on daily egg production assumed that all yolks ovulated were recovered as laid eggs or that the percentage of yolks lost between ovulation and oviposition was similar in normals and dwarfs;

(6) number of active or rapidly developing ova during the dye-feeding period and on postmortem examination. During the dye-feeding period, this number was obtained by counting the number of ova taking a certain dye of the dye sequence. These counts were made for each dye fed to a bird during the period and an average number of active ova was obtained for each bird. The number of active ova on postmortem examination was obtained by couting all the dye-stained ova in the ovary of each bird;

(7) body, liver weight and percentage of dry matter in the liver on postmortem examination.

\section{Statistical analysis}

Mean differences between genotypes were tested by the paired t-test. Each pair consisted of a normal Dw hen and a dw hen which was a full or half-sister of the former. The phenotypic correlations were calculated for all traits within genotypes. The correlations of the two genotypic groups were combined and calculated when they were homogeneous. 


\section{Results}

Table 1 presents the mean and the $d w / D w$ ratio (in percent )of the traits measured. Table 2 gives egg and yolk weight, time of laying, time between two ovipositions, time between the maturation of the ovum and its laying and the time required for rapid ovum development as related to clutch length and rank in the clutch. Table 3 shows the phenotypic correlations of all traits measured with the combined genotypes.

\section{TABLE 1}

Means of parameters concerning egg production, egg traits, anatomical and physiological traits.

Moyennes des paramètres concernant la production d'aufs, les caractéristiques des aufs, et des critères anatomiques et physiologiques.

\begin{tabular}{|c|c|c|c|c|c|}
\hline \multirow{3}{*}{ Parameters } & \multicolumn{4}{|c|}{ Genotype } & \multirow{3}{*}{$\frac{d w}{D w} \times 100$} \\
\hline & \multicolumn{2}{|c|}{ Dw } & \multicolumn{2}{|l|}{$\mathrm{dw}$} & \\
\hline & Mean & S.D. & Mean & S.D. & \\
\hline Body weight (g) & 1889.5 & 254.15 & $1266.5(* * *)$ & 132.35 & 67.03 \\
\hline Rate of lay (percent) & 59.44 & 17.34 & 52,30 & 21.26 & 87.99 \\
\hline Clutch size (days) $\ldots$ & 2.31 & 0.92 & 1.77 & 0.61 & 76.62 \\
\hline Egg weight $(\mathrm{g})$ & 59.12 & 2.84 & $52.84(*)$ & 4.39 & 89.38 \\
\hline Yo.k weight $(g) \ldots \ldots \ldots \ldots \ldots \ldots$ & 17.64 & 1.31 & $15.85^{(*)}$ & 1.28 & 89.85 \\
\hline Average daily yolk production (g) & 10.16 & 3.25 & $8.37(*)$ & 3.63 & 80.02 \\
\hline Hour of laying (hrs) $\ldots$ & 12.19 & 0.57 & 12.51 & 0.95 & 102.63 \\
\hline Time between two ovipositions (hrs) & 27.47 & 0.88 & 27.62 & 1.27 & 100.55 \\
\hline $\begin{array}{l}\text { Estimated time between the end of } \\
\text { yolk deposition in the ovum and ovi- } \\
\text { position (hrs) } \ldots \ldots \ldots \ldots \ldots \ldots\end{array}$ & 47.24 & 0.66 & $48.78^{(*)}$ & 1.53 & 103.26 \\
\hline $\begin{array}{l}\text { Duration of rapid development of } \\
\text { ovum (days) } \ldots \ldots \ldots \ldots \ldots \ldots \ldots\end{array}$ & 8.91 & 0.46 & 8.18 & 0.85 & 91.81 \\
\hline Weight of active ova (g) & 43.91 & 22.65 & $31.92(* *)$ & 17.65 & 72.69 \\
\hline Number of active ova at postmortem & 5.20 & 2.53 & $4.60^{(*)}$ & 2.01 & 88.46 \\
\hline $\begin{array}{l}\text { Number of active ova from dye fee- } \\
\text { ding } \ldots \ldots \ldots \ldots \ldots \ldots \ldots \ldots\end{array}$ & 5.66 & 1.04 & 4.54 & 1.55 & 80.07 \\
\hline Weight of liver $(\mathrm{g})$ & 42.43 & 10.08 & $3.1 .75(*)$ & 6.87 & 74.83 \\
\hline Percent dry matter in liver & 36.86 & 6.52 & 31.70 & 2.74 & 86.00 \\
\hline$(*)(* *) \quad(* * *)$ Difference between ger & types sig & cant at & $1,0.1$ p. 100 & respect & \\
\hline
\end{tabular}




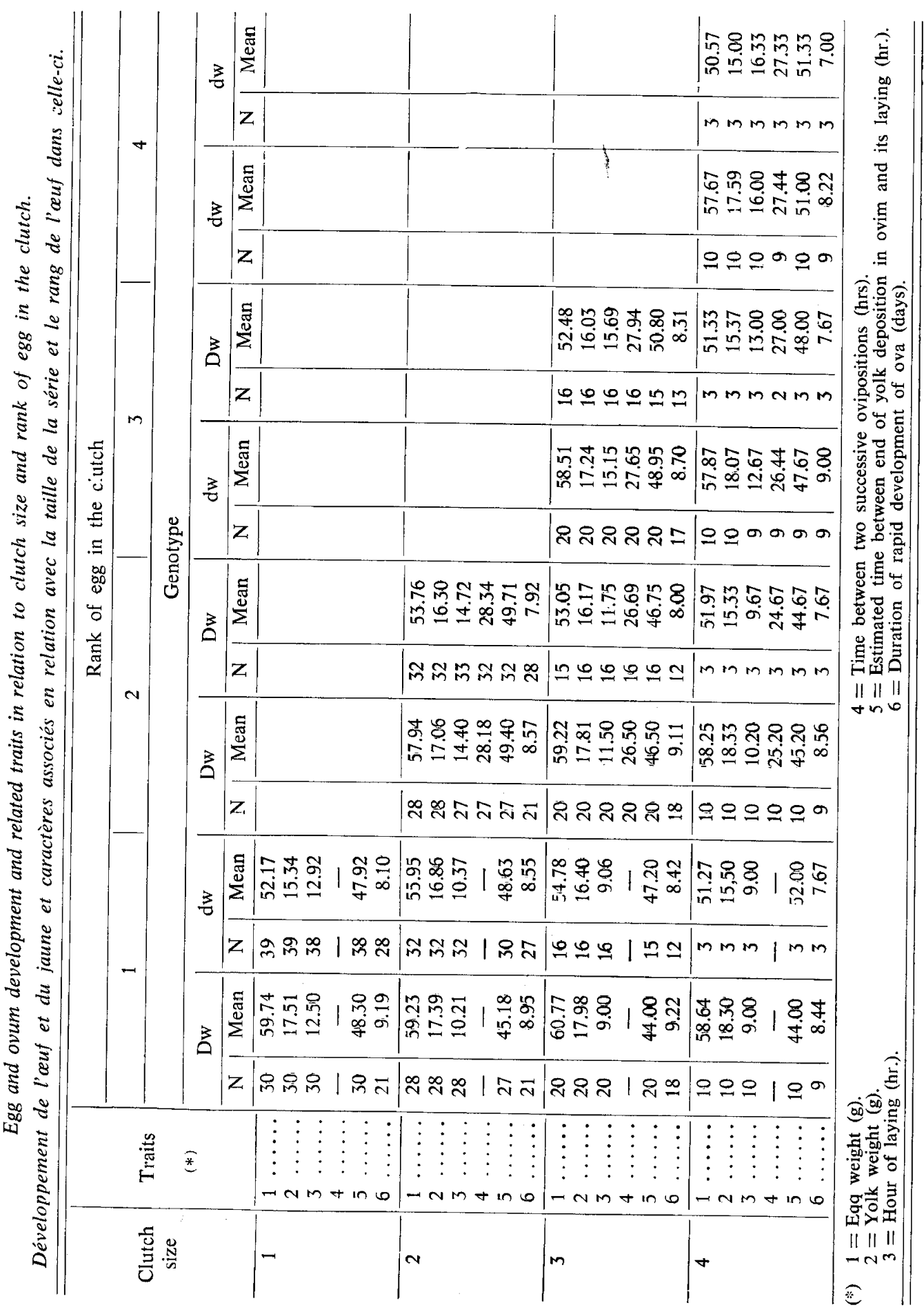




ह

ปี่

วิ

ปิ

站

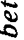

$m$

हี

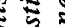

ำ ㄴํำ
हับ

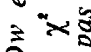

จ 0

ปั้

ธัँ :

号

अ

咅 $\frac{2}{2}$

उ०

ริ)

ำ

胥

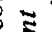

응

3 .

तั

825

ริ

पे के

ส้

$\stackrel{2}{2}$

$\frac{1}{0}$

ป

ปั

I

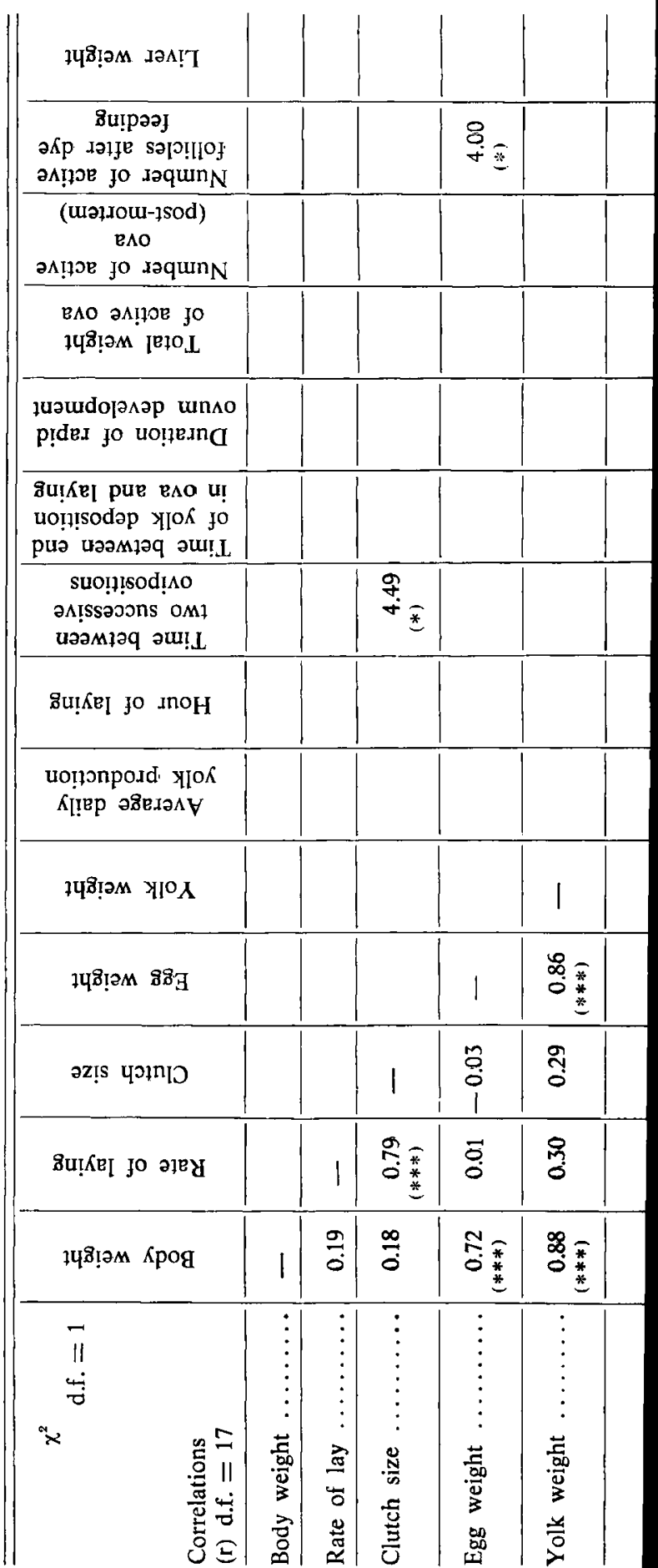




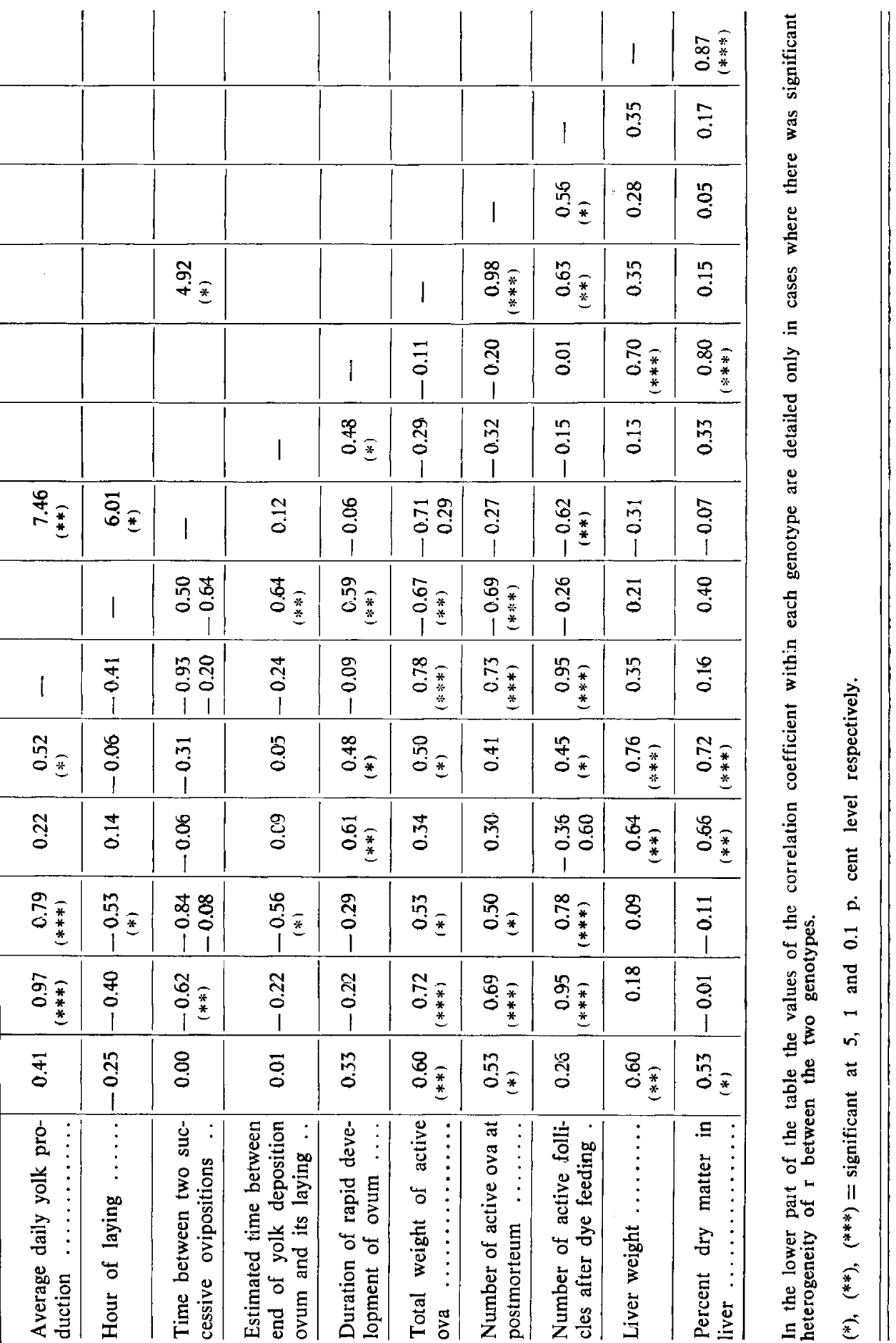




\section{Discussion}

\section{A. Means}

Table 1 shows a highly significant difference for body weight and a significant one for egg and yolk weight. Egg number and clutch size were not significantly different between Dw and dw during the 52-56-week period, although there was a very highly significant difference for these traits up to 39 weeks of age in a larger sample as well as in the present sample. Average daily yolk production and weight of active ova were significantly higher in the Dw genotype. The number of active ova estimated during the dye-feeding period was not significantly lower for dwarfs, while on postmortem examination it was significantly higher in the Dw genotype.

Although not significantly different, the time required for rapid development was longer for Dw hens $(8,91$ vs 8.18$)$. A similar trend was observed by JAAP \& Mohammadian (1969) working on broiler dams.

The average number of follicles undergoing rapid development at any one time, estimated from eggs laid during the dye-feeding period and the number of follicles observed on postmortem examination, corresponded well (Dw : 5.67 vs 5.20 ; dw : 4.54 vs 4.60 ). In the $\mathrm{Dw}$ genotype a slightly lower number on postmortem examination was due to the fact that two birds went out of production towards the end of the experiment. JAAP \& MoHAMMADIAN (1969) however observed a higher number of follicles on postmortem examination in the Dw genotype and explained this discrepancy as due to intra-peritoneal absorption of yolks in the Dw broiler dams.

While the time between two ovipositions was not significantly different between the genotypes, the estimated time between the end of ovum yolk deposition and laying was significantly higher in dwarfs. However, we cannot exclude a possible difference between Dw and dw hens as to the interval between dye feeding and dye deposition in the yolk.

Liver weights in Dw and dw genotypes were significantly different, representing 2.25 and 2.51 p. 100 of body weight, respectively. This is within the range of the 2 to 4 p. 100 of body weight reported by HAFEZ (1955) but lower than those reported by ShIVAPRASAD \& JAAP (1977) (3.3. to 3.6). The percentage of dry matter (36.9 and 31.7 in Dw and dw genotypes, respectively), although not significantly different, suggested that the moisture count of dwarf livers was higher than that of normals; this was in agreement with the work of SHIVAPRASAD \& JAAP (1977), although those authors found a higher dry matter percentage and a much smaller difference between the Dw and dw genotypes.

Table 2 shows that within each clutch size egg and yolk weights decreased in successive clutch positions in both $\mathrm{Dw}$ and dw genotypes. Dwarfs had no clutch size above 4 and thus we could not compare the genotypes. As the clutch size increased from 1 to 4 , the time of laying and the interval between two ovipositions appeared to decrease in the corresponding position of the clutch in both the Dw and dw genotypes. For all positions of the clutch up to clutch size 3, the time of laying in dwarfs was a little later compared to the Dw genotype. 
In both the Dw and dw genotypes, the hour of laying increased with successive clutch positions. The estimated time between the end of yolk deposition in the ovum and ovum laying followed a pattern similar to those of the hour of laying and the time between two ovipositions, i.e. it decreased in each corresponding position of the clutch as clutch size increased from 1 to 4 , and increased in the successive positions of the same clutch in both $\mathrm{Dw}$ and $\mathrm{dw}$ genotypes. For the first egg of clutches greater than one, this variable was $3 \mathrm{~h}$ longer in dwarfs. Thus, the first egg of the clutch in dwarfs may stay longer in the oviduct or require more time to ovulate.

The duration of rapid development of the ovum was shorter in dwarfs for clutches of all lengths and at all positions of the clutch. Within the genotype this duration represented a difference in ovum weight, and tended to be slightly less in the last egg having a clutch length of four. Also, rapid ovum development tended to last longer in the middle of clutches with more than three eggs. These variations observed in the length of rapid ovum development agree with the works of LACASSAGNE (1960) and BACON \& SKaLA (1968) who found that the last egg of clutches of more than one egg and the first egg of clutches of four or more eggs seemed to develop more rapidly than the eggs in the middle of these clutches.

\section{B. Correlations}

The phenotypic correlations between body, egg and yolk weights of combined genotypes were all positive and highly significant. The dependence of egg and yolk weights on body weight and of egg weight on yolk weight seemed to be closer in dwarfs. The highly significant correlation between body weight and the weight of active ova was more marked in dwarfs. The association of body weight with the number of active ova in the ovary on postmortem examination was significant. The correlation between body weight and duration of rapid ovum development was positive but non-significant.

The correlations of body weight with liver weight and the percentage of dry matter were positive and highly significant, suggesting a dependence of the liver characters on body weight, particularly in low body-weight birds.

As expected, the correlations of rate of lay with clutch size, average daily yolk production and weight and number of active ova were all positive and highly significant. Similarly, a number of correlations relating rate of lay, clutch size or yolk production traits with time parameters of ovum development or oviposition were significant. However, the positive association between egg or yolk weight and duration of rapid ovum development deserves to be mentioned, as no such correlation appeared with daily yolk production. The same may be said for the positive correlations between the yolk weight and the number of active follicles; these correlations were significant in the postmortem estimate of the latter trait, while small and non-significant correlations appeared between yolk weight on the one hand and rate of lay and clutch size on the other. Another correlation which is not explained $a$ priori is the one between the duration of rapid ovum development and the estimated delay between the end of yolk deposition in the ovum and ovum laying. There appeared to be no correlation in either genotype between rate of lay and liver weight and the percentage of hepatic dry matter. The correlations of the time between two successive ovipositions with clutch size, average daily yolk production and hour of 
laying were significantly different in $\mathrm{Dw}$ and $\mathrm{dw}$ genotypes. They were negative in both genotypes but were very highly significant in the Dw genotype. The correlation with hour of laying was positive in the Dw genotype but negative and significant in the dw genotype. These correlations in the Dw genotype suggest that more productive, early layers take less time to form their egg, while the dw genotype seems to need more time to form an early-laid egg. A proper physiological explanation for the above difference between the two genotypes is lacking at present.

The correlations of liver and percentage of hepatic dry matter wilth yolk weight were positive and highly significant, whereas the corresponding correlations with average daily yolk production were positive but not significant. SHIVAPRASAD \& JAAP (1977) observed that the rate of yolk production appeared to depend on liver weight and total liver lipids only in a strain carrying the dw gene.

Both liver traits were positively and significantly correlated with the duration of rapid ovum development. This association appears to reflect the positive significant correlation of liver weight with yolk weight which, in turn, was significantly correlated with the duration of rapid development. Average daily yolk production appeared to have no relation to the duration of rapid ovum development.

Received for publication in april 1982.

\section{Résumé \\ Production d'aufs et de vitellus en relation avec le développement de l'ovule, le poids et la teneur en eau du foie, chez des poules Leghorn blanches naines et normales}

Des données sur la production d'œufs et de vitellus et sur lè développement des ovules ont été obtenues sur des poules Leghorn blanches $\mathrm{Dw}$ et $\mathrm{dw}$ appartenant à 4 familles de pères, entre les âges de 52 et 56 semaines. Le développement des jaunes était. suivi par la technique d'incorporation de colorants liposolubles. A la fin de cette période, les poules étaient abattues et le poids corporel, le poids et la teneur en eau du foie, le poids et le nombre des ovules en phase degrand accroissement, étaient enregistrés. Les résultats suivants ont été obtenus :

1) La production moyenne journalière de jaune et le poids des ovules en accroissement rapide étaient plus élevés dans le génotype Dw. Le nombre des ovules en développement actif était plus grand chez les poules Dw, mais la différence entre génotypes n'était significative qu'à partir de l'examen post-mortem.

2) Le nombre moyen de follicules en développement rapide à un moment donné, estimé d'après la ponte durant la période d'ingestion des colorants, et le nombre observé à partir de l'examen après abattage, concordaient de façon satisfaisante dans les deux génotypes $D w$ et $d w$, suggérant l'absence de résorption intra-péritonéales de jaunes dans cette population.

3) Pour les séries de ponte de plus d'un auf, les naines pondaient le $1^{\text {er }}$ ouf de la série $3 \mathrm{~h}$ plus tard que les normales. Ceci peut provenir d'un séjour plus prolongé dans l'oviducte ou d'un retard à l'ovulation.

4) Quoique la différence ne soit pas significative dans l'ensemble, on remarque que la durée de la phase d'accroissement rapide des ovules dans les séries de toutes tailles, et dans toutes les positions à l'intérieur de chaque série, était plus courte chez les poules naines. 
5) L'intervalle de temps entre la fin du dépôt de vitellus dans l'ovule et l'oviposition était significativement plus long chez les naines.

6) Le poids du foie montrait une corrélation significative avec le poids des jaunes et la durée de la phase de développement rapide, à la fois chez les poules Dw et dw. Il n'était pas en corrélation avec le taux de ponte, et présentait une corrélation positive, mais non significative, avec le taux de production du vitellus dans les deux génotypes.

\section{References}

Bacon W.L., Skala J.H., 1968. Ovarian follicular growth and maturation in laying hens and their relation to egg quality. Poult. Sci., 47, 1437-1442.

Banerjee A.K., Bordas A., Mérat P., 1981. Sex-linked dwarf gene (dw) in White Leghorn laying hens under normal or hot temperature. Ann. Genet. Sel. anim., 14, 135-160.

Garlich J.D., Olson J.D., Hoff W.E., Hamilton P.B., 1975. Liver lipid content of twenty varieties of laying hens from three confinement systems. Poult. Sci., 54, 806-813.

HAFEZ E.S.E., 1955. Differential growth of organs and edible meat in the domestic fowl. Poult. Sci., 34, 745-753.

HutT F.B., 1959. Sex-linked dwarfism in the fowl. J. Heridity, 50, 209-221.

JAPP R.G., Mohammadian M., 1969. Sex-linked dwarfism and egg production of broiler dams. Poult. Sci., 48, 344-346.

KIYOSHI I., 1978. Rapid growth of the ovarian follicle in laying hens, with special reference to the clutch. 16th World's Poult. Congress, XIII, 32-37.

LaCassagne L., 1957. Dynamique de l'ovogenèse. Contribution à l'étude de la phase de grand accroissement des follicules chez la poule domestique. Ann. Zootech., 3, 85-93.

LaCassagne L., 1960. Etude comparée des réserves vitellines et de la durée de la phase de grand accroissement de l'ovocyte chez la poule domestique. Influence de l'âge de l'animal et de la longueur de la série. Ann. Zootech., 9, 85-96.

LACASSAGNE L., 1962. Eclairement quotidien et phase de grand accroissement de l'ovocyte chez la poule domestique. Proc. 12th World's Poultry Cong., 529-531.

LeVerlle G.A., 1969. In vitro hepatic lipogenesis in the hen and chick. Comp. Biochem. Physiol., 28, 431-435.

Merat P., 1969. Etude dun gene de nanisme lié au sexe chez la poule. Ann. Génét. Sél. anim., 1, 19-26.

O'HEA E.K., LeVeille G.A., 1968. Lipogenesis in isolated adipose tissue of the domestic chick (Gallus domesticus). Comp. Biochem. Physiol., 26, 111-120.

ShivaPrasad H.L., JAPP R.G., 1977. Egg and yolk production as influenced by liver weight, liver lipid and plasma lipid in three strains of small bodied chickens. Poult. Sci., 56, 1384-1390.

Warren D.C., Conrad R.M., 1939. Growth of the hen's ovum. J. Agr. Res., 58, 875-893. 